\title{
PRELIMINARY OBSERVATIONS ON THE BONE HISTOLOGY OF THE MIDDLE TRIASSIC PSEUDOSUCHIAN ARCHOSAUR BATRACHOTOMUS KUPFERZELLENSIS REVEAL FAST GROWTH WITH LAMINAR FIBROLAMELLAR BONE TISSUE
}

\author{
NICOLE KLEIN, ${ }^{*}, 1$ CHRISTIAN FOTH,${ }^{2}$ and RAINER R. SCHOCH ${ }^{1}$ \\ ${ }^{1}$ State Museum of Natural History Stuttgart, Rosenstein 1, 70191 Stuttgart, Germany, \\ nklein@posteo.de; rainer.schoch@smns-bw.de; \\ ${ }^{2}$ Department of Geosciences, University of Fribourg, Chemin du Musée 6, 1700 \\ Fribourg, Switzerland; christian.foth@gmx.net
}

\begin{abstract}
The bone tissue of femur, rib, and gastralia from three different individuals of the Middle Triassic pseudosuchian Batrachotomus kupferzellensis from southern Germany is studied. The femoral bone tissue comprises laminar fibrolamellar bone tissue throughout and is stratified by three annual growth cycles, indicating that the individual died early in its fourth year of life, at which time it had reached $87 \%$ of maximum known femur length. Thus, compared with most other Pseudosuchia (e.g., phytosaurs, aetosaurs, and most crocodylomorphs, including marine taxa), Batrachotomus achieved its large body size in a very short time by fast, although interrupted, growth and not by protracted longevity. Such fast growth as well as the organization of the tissue is similar to the condition observed in ornithodirans. The pseudosuchians Effigia and Postosuchus also show fibrolamellar tissue, but vascular density is lower when compared with Batrachotomus and dominated by a longitudinal organization of primary osteons. The rib and gastralium of Batrachotomus both show an inner spongious organization surrounded by a ring of compact, avascular, highly organized parallel-fibered and/or lamellar bone largely covered by short fibers. Maximal growth cycle count in the proximal rib sample suggests an age of at least 11 years for this individual with a reduction of growth rate after the sixth cycle.
\end{abstract}

SUPPLEMENTAL DATA—Supplemental materials are available for this article for free at www.tandfonline.com/UJVP

\section{INTRODUCTION}

Understanding aspects of growth provides crucial data for the reconstruction of life history strategies in long-extinct clades, because the pattern of growth is impacted by ontogenetic development, metabolism, and external environmental factors (Karkach, 2006). Two divergent tissue types are found in extant tetrapods, reflecting two main growth patterns: lamellar-zonal bone (LZB) and fibrolamellar bone tissue type (FLB). According to Francillon-Vieillot and colleagues (1990:204), LZB is dominated by a bone tissue matrix of parallel-fibered or lamellar bone, extensively stratified by cyclical growth marks. Vascular density is low or tissue may be even avascular. FLB consists largely of woven and centripetally deposited lamellar bone (primary osteons), and the matrix shows a high vascular density (Francillon-Vieillot et al., 1990; Cubo et al., 2005; Legendre et al., 2016). Like LZB, FLB can be stratified by growth marks, as was described for some dinosaurs (Horner et al., 2000; Horner and Padian, 2004; Klein and Sander, 2007) and mammals (e.g., Sander and Andrássy, 2006; Köhler et al., 2012). Amprino (1947) recognized that there is a connection between bone tissue and growth rate (the slower the deposition rate, the more regular is the orientation of the collagen fibers), although this has been difficult to quantify (Castanet et al., 2000; de Margerie et al., 2002; Montes et al., 2007).

*Corresponding author.
Recent lissamphibians and non-avian reptiles typically form LZB (Castanet et al., 1993). By contrast, most living birds and mammals deposit FLB (Chinsamy and Elzanowski, 2001; Köhler et al., 2012). There is consensus that bone tissue type (reflecting growth rates) and metabolism are related (e.g., Legendre et al., 2013), but growth rates of endothermic and ectothermic extant taxa can overlap.

In Mesozoic diapsids, the variety of combinations among bone tissues and vascular systems (e.g., Ricqlès et al., 2003, 2008; Chinsamy-Turan, 2005; Botha-Brink and Smith, 2011; Sander et al., 2011; Houssaye, 2013; Erickson, 2014; Houssaye et al., 2014; Klein et al., 2015a, 2015b) documents a much higher histological diversity that correlates with various growth patterns and life history strategies, as well as an implied broader metabolic range/diversity than observed in modern tetrapods (e.g., Castanet et al., 1993; Köhler et al., 2012). Ichthyosaurs (Buffrènil and Mazin, 1992; Houssaye et al., 2014) and some Sauropterygia (Buffrènil and Mazin, 1990; Wiffen et al., 1995; Klein et al., 2015a) are so far the only known non-archosaur diapsids that formed FLB throughout most of their ontogeny, which might be related-at least in Triassic forms - to a constant warm environment.

Archosauria is divided into two major clades: the Pseudosuchia, which includes modern crocodilians and all archosaurs more closely related to crocodilians than to birds, and the Avemetatarsalia or Ornithodira, which contains pterosaurs, silesaurids, and dinosaurs, including birds (Nesbitt, 2011). The 
Pseudosuchia were most successful and diverse (both ecologically and morphologically) during the Late Triassic (Brusatte et al., 2008; Foth et al., 2016), including quadrupedal and (facultative) bipedal forms, terrestrial and semiaquatic life styles, as well as piscivorous, carnivorous, or omnivorous diet preferences (e.g., Desojo and Vizcaíno, 2009; Gauthier et al., 2011; Nesbitt et al., 2013). According to Nesbitt (2011), Pseudosuchia contain Ornithosuchidae, Aetosauria, Poposauroidea, Rauisuchidae, and Crocodylomorpha, but probably also the long-snouted Phytosauria (see Brusatte et al., 2010; Ezcurra, 2016). Except for Crocodylomorpha, the group went extinct at the end of the Triassic (Nesbitt, 2011; Toljagic and Butler, 2013).

Within Pseudosuchia, Batrachotomus kupferzellensis was a large ( $\sim 6 \mathrm{~m}$ body length), common apex predator in the Middle Triassic Lower Keuper deposits of southern Germany (Kupferzell and Vellberg, Baden-Württemberg) (Gower, 1999; Gower and Schoch, 2009; Schoch and Seegis, 2016). It was quadrupedal, and its postcranial morphology suggests an erect posture (see Benton, 1984). Batrachotomus was formerly thought to be a member of Prestosuchidae (Gower, 2002; Brusatte et al., 2010), but other phylogenetic analyses found it more closely related to Crocodylomorpha and Rauisuchidae (Nesbitt, 2011; Li et al., 2012; Sues and Schoch, 2013).

\section{Previous Works on Basal Archosaur Bone Histology}

Ricqlès and colleagues $(2003,2008)$ were among the first who studied bone tissue of several pseudosuchian and basal archosauriforms. Since then, more studies on archosauromorphs, archosauriforms, and pseudosuchian archosaurs have been conducted. Most studied taxa comprise a mixture of bone tissues that usually early in ontogeny form FLB to later switch to LZB (e.g., Ricqlès et al., 2003, 2008; Botha-Brink and Smith, 2011; Werning and Nesbitt, 2016). Their tissue is interrupted by a high number of cyclical growth marks with broad zones alternating with broad annuli capped by a line of arrested growth (LAG; e.g., Ricqlès et al., 2003, 2008; Botha-Brink and Smith, 2011; Werning and Nesbitt, 2016). Osteoderm histology of phytosaurs and aetosaurs (Scheyer et al., 2014) as well as that of several 'rauisuchians,' including Batrachotomus (Scheyer and Desojo, 2011; Cerda et al., 2013), documents a similar diverse distribution of bone tissues in these taxa, as is seen in their long bones.

Instead, ornithodirans such as dinosaurs (e.g., Ricqlès, 1968; Horner et al., 2000; Chinsamy-Turan, 2005; Erickson, 2005, 2014; Sander et al., 2011) and pterosaurs (e.g., summarized in Steel, 2008) formed FLB through most of their ontogeny, indicating sustained high growth rates. Their tissue is interrupted by a relatively lower number of broad zones alternating with thin annuli or LAGs (Ricqlès et al., 2003). In addition, the vascular system differs between ornithodirans and pseudosuchians: dinosaurs usually show a laminar or plexiform and pterosaurs a reticular organization, whereas in pseudosuchians vascularization is dominated by longitudinal canals (Ricqlès et al., 2003). Despite the presence of FLB in the inner cortex, the tissue type of pseudosuchians is usually categorized as LZB due to the dominance of parallel-fibered and lamellar bone throughout the cortex (Ricqlès et al., 2003, 2008). However, some exceptions occur, such as the large archosauriformes Erythrosuchus and crocodylomorph Terrestrisuchus, which largely grew with FLB (Ricqlès et al., 2003; Botha-Brink and Smith, 2011).

In summary, most pseudosuchians had high growth rates only early in development, and large adult sizes were reached through protracted cyclical growth, resulting in high numbers of growth marks (Ricqlès et al., 2003, 2008). Contrary to this is the potential of ornithodirans to reach large body sizes quickly, resulting in a lower number of growth marks until attaining maximum size (Ricqlès et al., 2008; see also Sander et al., 2004, for accelerated growth in Sauropoda). However, due to limited sampling, the evolution of growth patterns in basal archosauromorphs, including pseudosuchians, is still poorly understood.

In the current study, we analyze bone histology and microanatomy of a femur, a rib, and parts of gastral ribs of three different individuals of the large-bodied pseudosuchian Batrachotomus kupferzellensis and compare bone tissue and growth pattern with those of other basal archosauromorphs, on a morphological and a phylogenetic level.

Institutional Abbreviation-SMNS, Staatliches Museum für Naturkunde Stuttgart, Germany.

\section{MATERIALS AND METHODS}

The midshaft of an almost complete but dorsoventrally heavily crushed left femur of Batrachotomus kupferzellensis (SMNS 90509; Gower and Schoch, 2009) from the locality of Kupferzell was sampled (Fig. 1A). The crushed condition of the femur is most likely the result of the compaction of argillites and marls between diagenetic cemented dolomite banks, characterizing the rocks of the locality (Schoch and Seegis, in press). Here, another midshaft break of a non-compacted femur (SMNS 52970) helps to confirm that the medullary cavity in SMNS 90509 is actually small and not secondarily compacted (Fig. 1D). The sampled femur measures approximately $42 \mathrm{~cm}$, which is $87.9 \%$ of the thus far longest known femur (SMNS 52970) of Batrachotomus, which measures $47.8 \mathrm{~cm}$ (Gower and Schoch, 2009). In addition, three thin sections along the midshaft region of a dorsal rib (SMNS 92130) and of a gastral rib (SMNS 92131) were sampled, respectively (Fig. 1B, C). The samples all originate from the same locality and horizon but belonged to different individuals.

The thin sections were produced following standard petrographic methods (Klein and Sander, 2007) and had a thickness of between 55 and $72 \mu \mathrm{m}$. Thin sections were studied and photographed with a Leica DM 750P compound polarizing microscope equipped with a digital Leica ICC50HD camera. Cross-sections were scanned with an Epson V740 PRO high-resolution scanner (Fig. 2). The bone histological terminology follows Francillon-Vieillot et al. (1990).

Due to compression of the cross-section, the overall femoral growth rate was calculated by measuring the cortical thickness of all four bone sides and dividing the resulting average value by four. This value was then divided by the number of years counted from the sample, using a year of 380 days (see Botha-Brink and Smith, 2011).

To trace evolutionary patterns of growth in basal archosauromorphs from the Permian and Triassic periods, we mapped the occurrence of different types of bone tissue onto a phylogenetic hypothesis for basal archosauromorphs, using the 'trace history' function in the program Mesquite 3.2 (Maddison and Maddison, 2017). Three different growth pattern states were defined: formation of LZB through whole ontogeny (0), formation of FLB only during early ontogenetic stages with subsequent formation of LZB for remaining life time (1), and intense formation of FLB over longer ontogenetic period (2). The histological data were taken from the literature (see Supplementary Data, Table S1). For the phylogeny of archosauromorphs, an informal supertree was created. The relationships of stem archosaurs follows Ezcurra (2016), whereas the topology of crown archosaurs is based on Nesbitt (2011). Because of conflicting results, we considered two different phylogenetic positions for phytosaurs: as a sister group to Archosauria (Nesbitt, 2011) and as the most basal member of Pseudosuchia (Brusatte et al., 2010; Ezcurra, 2016). To test the strength of the phylogenetic signal for the growth patterns in archosauromorphs, we reshuffled the character states 10,000 times across the tree while the topology was held constant. Afterwards, we compared the number of steps with the original character mapping. If the original number of steps was smaller than in $95 \%$ of the randomized character states, growth 
A

FIGURE 1. Sampled bones of Batrachotomus kupferzellensis from the late Ladinian (Middle Triassic) of southern Germany with the respective sampling locations marked by white arrows. A, left femur (SMNS 90509) in ventral view; B, fragment of Batrachotomus kupferzellensis dorsal rib (SMNS 92130); C, fragment of gastralium (SMNS 92131); D, midshaft cross-section (natural break) of largest known femur (SMNS 52970) of Batrachotomus kupferzellensis exhibiting a central free medullary cavity now filled with dolomitic marlstone (black arrows).

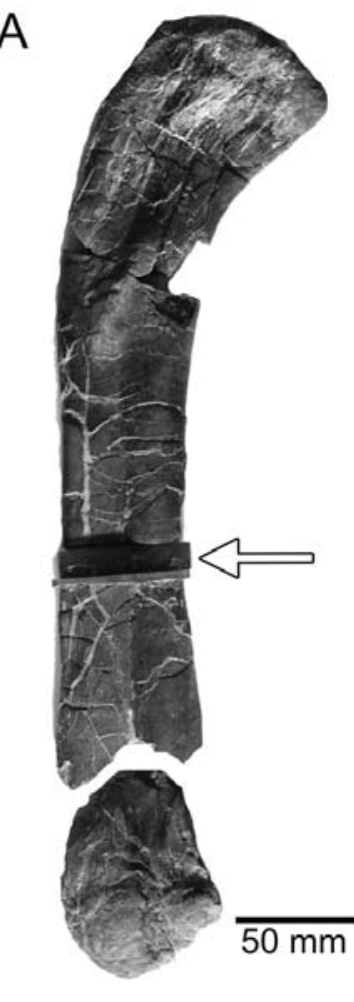

B
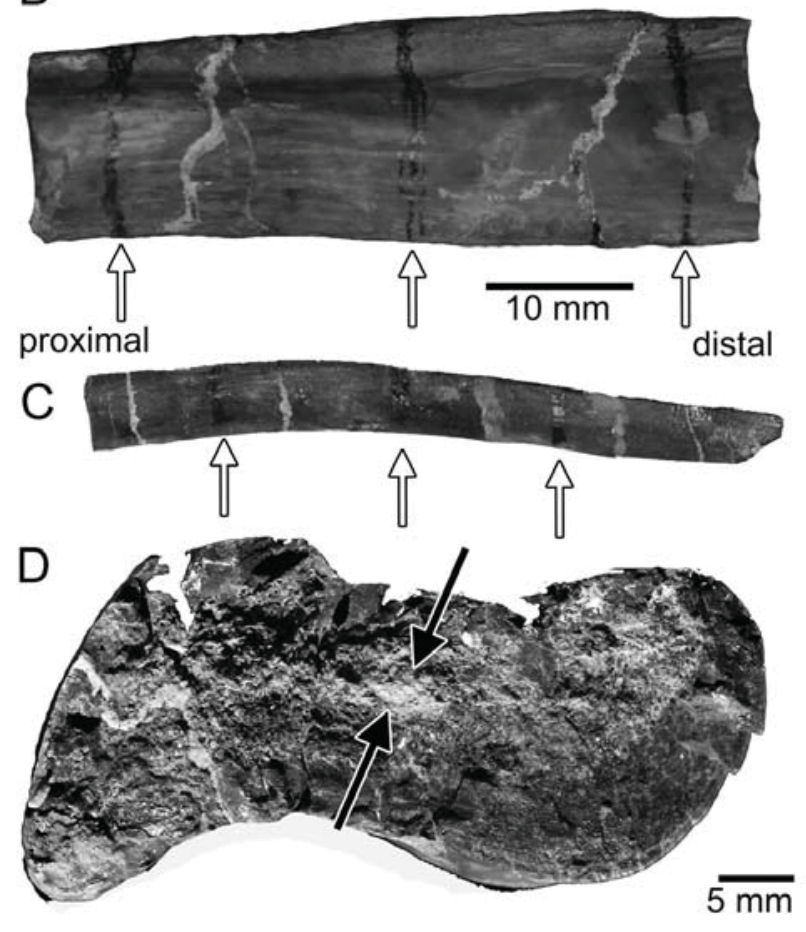

patterns in archosauromorphs are considered to be phylogenetically constrained.

\section{RESULTS}

\section{Histological Description}

Femur-Due to compaction of the femur (SMNS 90509), the entire cross-section is traversed by cracks and fissures (Fig. 2A, B). The outer bone surface is in many places incomplete or crushed. The medial and lateral bone sides are best preserved, whereas the dorsal and ventral sides experienced most damage, indicating dorsoventrally directed pressure. Ventrolaterally, a funnel-shaped, sediment-filled crack reaches deep into the cortex (Fig. 2A, B).

In the lateromedial direction, an elongated crack runs through the center of the cross-section, most likely tracing and expanding the free, but small medullary cavity (Fig. 2A, B). The free cavity was surrounded by secondary trabeculae comprising erosion cavities, which are now largely collapsed and compressed due to damage/compaction during fossilization (Fig. 3A). Thicker fragments of lamellar (endosteal) bone aligned parallel to the dorsoventral bone surfaces indicate partial lining of the cavity margin by endosteal bone (Fig. 3A). Large erosion cavities occur scattered up into the middle cortex (Figs. 2, 3A). True Haversian bone is not deposited, but some of the smaller round erosion cavities lined by lamellar (endosteal) bone can be interpreted as young (immature) secondary osteons (Currey, 2002; Fig. 3A).

The vascular system is dominated by a laminar organization but can become locally (sub-)plexiform (Figs. 2-4). The shape of the vascular canals is circumferential, longitudinal, and reticular. Vascular density is higher on the lateral side of the bone (Fig. 2). Vascular canals are surrounded by primary osteons (Fig. 4).

The primary bone tissue consists of woven-fibered bone with numerous round osteocyte lacunae and primary osteons, resulting in fibrolamellar bone tissue (Figs. 2, 4A, B). Locally, the woven-fibered bone component is intermixed with parallelfibered bone (Fig. 4C, D).

The cortex is stratified by annual growth cycles consisting of broad zones, forming most of the cortex, and narrow/thin annuli (Figs. 2, 3B-D). The zones start with numerous and large primary osteons in the inner, but their number gradually decreases towards the outer zone. Zones are made of woven-fibered and low-organized parallel-fibered bone. Annuli are avascular and narrow/thin, consisting of highly organized parallel-fibered bone tissue. Three distinct annuli can be counted, of which one forms the outer cortex (Fig. 3B-D).

Except for the lateral bone side (Fig. 3D), vascular density decreases somewhat and tissue organization increases towards the outer cortex, but a change to an external fundamental system (sensu Horner et al., 2000) is not observed (Fig. 3B, C). The cortex of the dorsal and ventral bone sides is generally more organized and contains locally thin layers of avascular parallelfibered bone that, however, cannot be followed throughout the entire cross-section and are thus interpreted as non-annual cycles (subcycles; see Klein et al., 2015b). Growth rate had decreased in the outer cortex of the ventral and dorsal bone sides due to higher organization of bone tissue and decreased vascular density (Fig. 3C), but vascular density is still high medially and laterally (Figs. 2, 3B, D), indicating that the individual was not fully grown. During the recorded growth period, this individual grew on average (see Materials and Methods) at a daily rate of ca. $16.0 \mu \mathrm{m} /$ day (assuming 3 years of fast growth).

Dorsal Rib-The shape of the cross-sections taken from the dorsal rib (SMNS 92130) changes from the proximal to the distal part from roundish-triangular to elliptical (Fig. 5A-B). Over all, the area accommodating the prominent ventral ridge is concave, whereas the other margins are convex or straight. The rib samples all share a spongious inner structure (Fig. 5A-B, F-G). The spongiosa consists internally of large central erosion cavities connected by secondary trabeculae forming a medullary region. The medullary region grades into a remodeling zone that is 


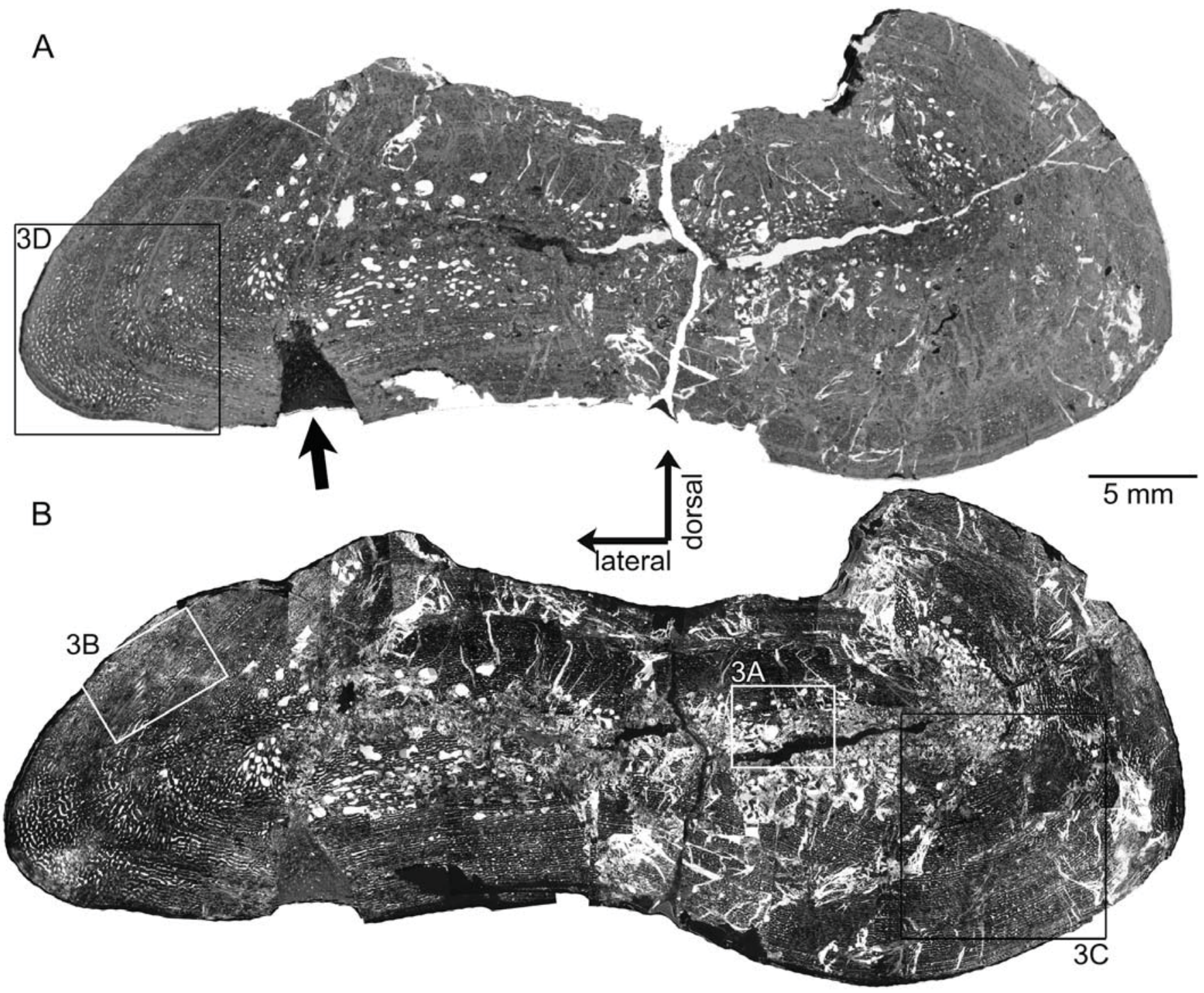

FIGURE 2. Cross-sections of the femur of Batrachotomus kupferzellensis (SMNS 90509). A, midshaft cross-section in plane polarized light. Ventrolaterally, a funnel-shaped crack reaches deep into the cortex (black arrow); B, composite photograph of midshaft cross-section under crossed nicols depicting the mainly laminar vascular organization. The rectangles correspond to the microphotographs depicted in Figure 3.

characterized by smaller erosion cavities transforming locally into secondary osteons. Scattered erosional cavities reach far into the outer cortex, mainly in a lateromedial direction (Fig. 5A-B). Vascularization is low and consists of small, simple vascular canals and few primary osteons all arranged longitudinally (Fig. 5F). The inner cortex, if visible between the erosional cavities, consists of parallel-fibered bone tissue. In the outer cortex, higher-organized parallel-fibered bone tissue grades into lamellar bone, which is stratified by numerous rest lines. Additionally, the primary bone tissue in the outer cortex is dominated by long Sharpey's fibers and shorter fibers (Fig. 5G-H). Osteocyte lacunae are numerous but remain small. The middle to outer rib cortex is stratified by LAGs. At least 11 LAGs are counted in the proximal section, which reveals according to Waskow and Sander (2014) the most complete growth record in the rib. The last five LAGs deposited in the outer cortex are more closely spaced than the LAGs in the middle cortex (Fig. 5A), indicating a reduction in growth rate.
Gastralium-A part of a gastralium was thin-sectioned three times along its shaft. The cross-sections are all elliptical (Fig. 5C-D). All three samples show large de-central medullary regions that contain large erosion cavities connected by secondary trabeculae. Mainly towards the mediolateral side, smaller erosion cavities are scattered in the cortex. The bone tissue of the gastralium is avascular and consists of highly organized parallel-fibered bone interspersed with short fibers (Fig. 5I). Osteocyte lacunae are very small but numerous. The cortex is stratified by numerous rest lines.

\section{DISCUSSION}

The three elements of Batrachotomus clearly demonstrate interelemental histovariability. The femur indicates fast growth by the presence of fibrolamellar bone tissue in a laminar to (sub-)plexiform organization, whereas rib and gastralium show low-vascularized to nearly avascular lamellar-zonal bone tissue 

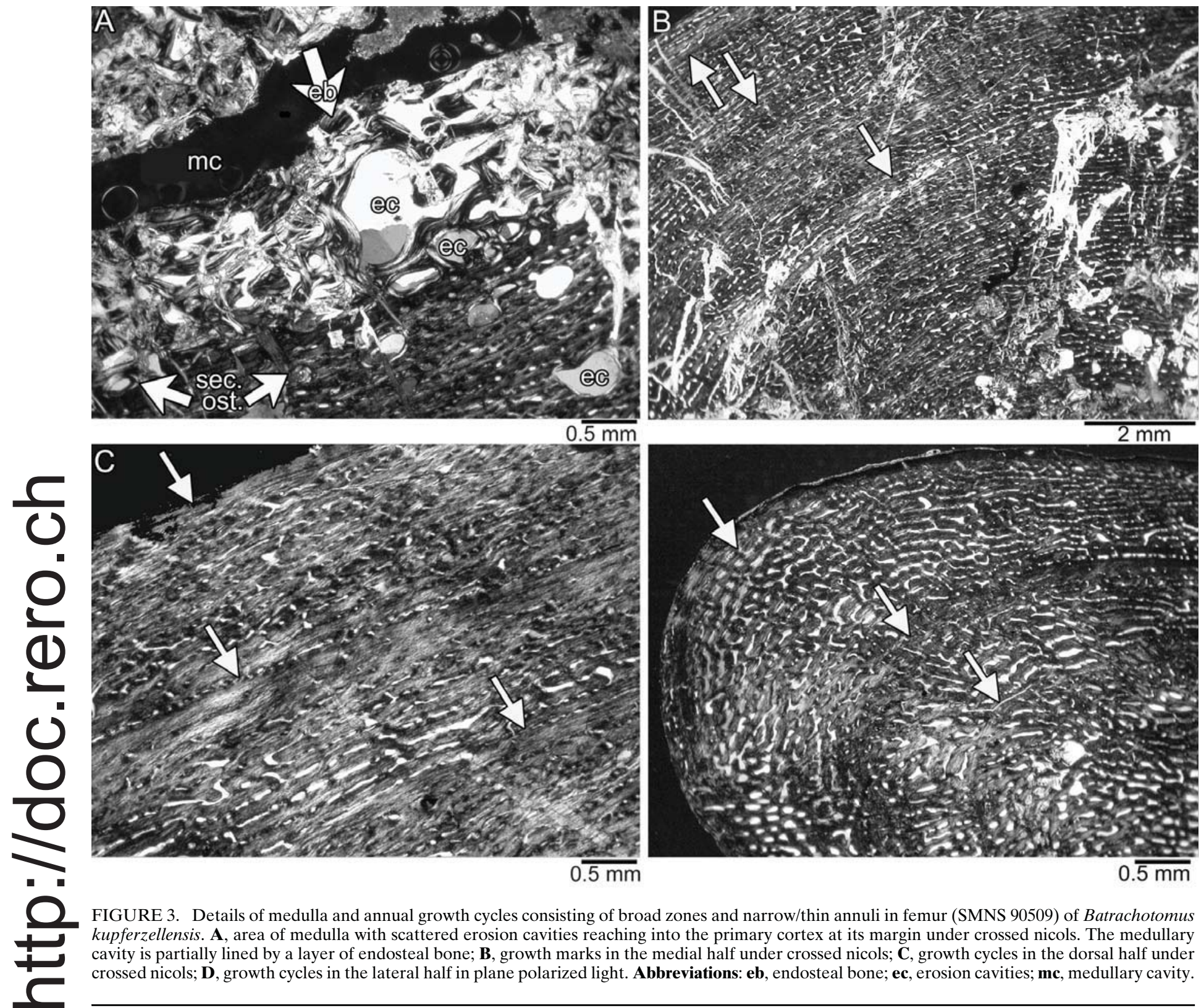

$0 . \overline{\mathrm{mm}}$

$0 . \overline{5 \mathrm{~mm}}$

FIGURE 3. Details of medulla and annual growth cycles consisting of broad zones and narrow/thin annuli in femur (SMNS 90509) of Batrachotomus kupferzellensis. A, area of medulla with scattered erosion cavities reaching into the primary cortex at its margin under crossed nicols. The medullary cavity is partially lined by a layer of endosteal bone; $\mathbf{B}$, growth marks in the medial half under crossed nicols; $\mathbf{C}$, growth cycles in the dorsal half under crossed nicols; $\mathbf{D}$, growth cycles in the lateral half in plane polarized light. Abbreviations: eb, endosteal bone; ec, erosion cavities; mc, medullary cavity.

type and the presence of fibers all over the primary cortex. Sauropodomorph dinosaurs such as Plateosaurus and Camarasaurus also show fibrolamellar bone tissue in their long bones and zonal primary bone dominated by fibers in their ribs (N.K., pers. observ., 2007; Waskow and Sander, 2014). Differences in the annual growth mark count (three growth marks in the femur vs. 11 growth marks in the rib) are related to the fact that different individuals were sampled representing different ontogenetic stages with different individual ages. Based on the femur histology, our study documents that Batrachotomus had the ability to grow very fast and reached its large body size within a few years and not by protracted longevity as do most pseudosuchians (including extant crocodylians).

Bone histological data of dinosaurs and pterosaurs are numerous, and all support the general statement of Ricqlès et al. (2003) that ornithodirans formed FLB throughout most of their ontogeny, indicating sustained high growth rates. Fast growth rates in ornithodirans throughout most of ontogeny were also supported by Cubo et al. (2012). Data on archosauromorphs, archosauriforms, and pseudosuchian archosaurs, however, are still rare (and less well understood) but so far show a variety of bone tissues and vascular systems, resulting in a mixture of bone tissue patterns (Botha-Brink and Smith, 2011). The primary bone tissue type of non-ornithodiran archosauromorphs can be characterized (with a few exceptions, see below) as lamellar-zonal bone tissue type/LZB (Ricqlès et al., 2003, 2008; Botha-Brink and Smith, 2011; Werning and Irmis, 2011; Ezcurra et al., 2014; Mukherjee, 2015; Veiga et al., 2015; Werning and Nesbitt, 2016). Differences with modern reptiles that also grow with LZB are mainly related to vascularity (density and organization) and a higher organization of tissue.

The character mapping (Fig. 6), however, indicates that the last common ancestor of Archosauromorpha already possessed the ability to form FLB in ontogeny (see also Ricqlés et al., 2003, 2008; Botha-Brink and Smith, 2011; Legendre et al., 2013), with three independent secondary losses (characterized by the formation of LZB only) in stem archosaurs (i.e., Trilophosaurus, Stenaulorhynchus, and Vancleavea) and one or two times in the 
growth rate. The latter still differ by their vascular system, which shows a mainly longitudinal orientation of vascular canals, whereas that of Batrachotomus is dominated by a laminar to (sub-)plexiform organization. Postosuchus and Effigia further form secondary osteons and have an EFS deposited in their outer cortex (Ricqlès et al., 2003; Nesbitt, 2006), indicating that ontogenetically older individuals were sampled. The lack of an EFS as well as of secondary osteons in the Batrachotomus femur could be related to the relatively young age of the individual sampled. Further, Postosuschus has a much higher preserved number of growth cycles (20 in the humerus; Ricqlès et al., 2003), when compared with Batrachotomus, whereas in Effigia the number of annual growth cycles is similar (around six growth cycles in the femur according to Nesbitt, 2006). By contrast, the sample of Terrestrisuchus clearly originated from a young individual, as is indicated by the low number of growth marks (two LAGs) and by the lack of any remodeling and an EFS (Ricqlès et al., 2003), similar to the femur sample of Batrachotomus. The calculation of the daily growth rate revealed $14.52 \mu \mathrm{m} /$ day for Postosuchus (Legendre et al., 2013), $11.3 \mu \mathrm{m} /$ day for Proterosuchus (Botha-Brink and Smith, 2011), 7-10 $\mu \mathrm{m} /$ day for Terrestrisuchus (Padian et al., 2004), and around $16.0 \mu \mathrm{m} /$ day in Batrachotomus. The high growth rate documented in the femur of Batrachotomus might be related to its young age, whereas one has to consider that growth rate decreases with further age (see Erickson, 2005). Batrachotomus is so far unique from the others, because it is the only member of Pseudosuchia growing with laminar to (sub-)plexiform FLB until over two-thirds of maximum body/femoral length is reached.

A bone tissue structure with broad growth zones and narrow annuli as well as fast growth in early ontogeny is more typical for ornithodirans. Likewise, Ornithodira typically grew with FLB, in which the growth rates of non-avian dinosaurs range from 3 to $24 \mu \mathrm{m} /$ day (Sander and Tückmantel, 2003), with $10.5 \mu \mathrm{m} /$ day in the sauropod Apatosaurus (Curry, 1999) and $7.6 \mu \mathrm{m} /$ day in the prosauropod Plateosaurus engelhardti (this study; femur 1 of Klein and Sander, 2007). However, these growth rates overlap with those found for some pseudosuchians (independent of whether they grew with FLB or LZB, see above), indicating that growth rates (in contrast to the bone tissue structure itself) may not be a good proxy for phylogenetic or physiological analyses.

However, the comparison of growth rates of extinct vertebrates remains difficult for many reasons, including methodical problems with the calculation itself. Further problems are related, for example, to an unclear number of annual growth cycles due to loss of inner cycles or how the annual growth marks are counted, that is, whether all annual growth cycles are considered (average growth rate) or only those of juvenile growth or those during fast growth periods, respectively. Further methodological problems concern differences in cortex thickness around the cross-section due to natural shape and postburial compaction or to the number of days per year that are considered for the period of active growth. A second problem concerns the wide range of growth rates of a tissue type resulting in an overlap of growth rates of different tissues (Starck and Chinsamy, 2002 Montes et al., 2010), and finally, the problem due to "substantial variation [...] among different elements of a single individual and within a single bone type" (Botha-Brink and Smith,
2011:1250; see also Woodward et al., 2014). Such distinct variations are also supported by the differences in histology between the femur and the rib and gastralium of Batrachotomus.

Based on the current data situation, however, Batrachoto$m u s$ and some other pseudosuchians represent an exception from the observation made by Montes et al. (2010) and Cubo et al. (2012), who found a successive decrease in bone growth rates from the last common ancestor of Pseudosuchia to extant crocodiles. However, the common high growth rates and the possibility to grow with FLB in early archosauromorphs and pseudosuchians support the hypothesis of Ricqlés et al. $(2003,2008)$ who stated that "reaching and maintaining very high growth rates through ontogeny could have been a basal characteristic of archosauriforms." The reason why some pseudosuchians grow faster than others, however, remains unclear. Possible triggers for fast growth in Batrachotomus might be in response to environmental parameters (Botha-Brink and Smith, 2011; Botha-Brink et al., 2016), respiration and metabolic rates (Cubo et al., 2012; Seymour et al., 2004), large body size (Padian and Horner, 2004), a possible earlier onset of sexual maturity (Karkach, 2006), or an erect stance combined with an active predatory life style (Benton, 1984; Seymour et al., 2004). For instance, in an unstable environment, fast growth and earlier maturity may have been favorable (Botha-Brink et al., 2016), which is in agreement with the supposed habitat of Batrachotomus. In the Kupferzell locality, fluctuating growth marks in the temnospondyl Gerrothorax pulcherrimus have been interpreted as evidence for unstable environmental parameters (Witzmann et al., 2012) so that the fast growth rates present in Batrachotomus may have been an advantage to an apex predator niche in the ecosystem (Both-Brink et al., 2016). Thus, besides phylogenetic constraints, the bone tissue of Batrachotomus probably includes an adaptational signal, as was suggested several times before (Ricqlès et al., 2003, 2008; BothaBrink and Smith, 2011; Veiga et al., 2015).

The rib and gastralium of Batrachotomus both follow the lamellar-zonal pattern and do not show FLB. However, in both elements, the tissue consists largely of short fibers. The inner cortex of the dorsal rib samples is built of low-vascularized parallel-fibered tissue interrupted by widely spaced LAGs. The outer cortex consists of avascular tissue containing several closely spaced LAGs. The proximal rib sample reveals a reduction in growth rate, indicated by a closer spacing of LAGs after LAG 6. The comparison of the rib of Batrachotomus with several modern taxa (lepidosaurs, archosaurs, and mammals) supports the results of Canoville et al. (2016) that rib microstructure is largely related to body size (and to a lesser amount to life style), because Batrachotomus shares with most larger taxa the presence of a spongiosa surrounded by a ring of compact cortex (Canoville et al., 2016).

So far, only gastralia of aquatic vertebrates have been histologically studied (summarized in Klein and Scheyer, 2017), all of which are more osteosclerotic when compared with that of Batrachotomus. For comparison, we examined the midshaft break of a gastralium of the terrestrial prosauropod dinosaur Plateosaurus (Fig. 5E). The microstructure is also much more

$\leftarrow$ FIGURE 5. Histology and microanatomy of rib and gastralium of Batrachotomus kupferzellensis. A, composite of proximal cross-section of dorsal rib (SMNS 92130) in plane polarized light; $\mathbf{B}$, composite of distal cross-section of dorsal rib (SMNS 92130) in plane polarized light; $\mathbf{C}$, cross-section of proximal gastralium (SMNS 92131) under crossed nicols; D, cross-section of distal gastralium (SMNS 92131) under crossed nicols; E, cross-section (natural break) of a gastralium of Plateosaurus (SMNS F5). F-H, histological details of dorsal rib samples (SMNS 92130). Note the spongious inner structure and the large amount of fibers in the primary bone tissue; $\mathbf{F}$, single-headed arrows mark LAGs in the proximal rib sample in plane polarized light; G, transitional area between medullary region and primary tissue largely made of fibers under crossed nicols; $\mathbf{H}$, transition between inner and outer cortex where LAGs become more closely spaced in plane polarized light; I, histological details of the gastralium (SMNS 92131) depicting the spongeous inner and primary tissue made of short fibers under crossed nicols. Abbreviations: ISf, long Sharpey's fibers; po, primary osteons; ssf, short fibers; svc, simple vascular canal. 


\section{ACKNOWLEDGMENTS}

We are indebted to N. Adorf, I. Rosin, and M. Kamenz (SMNS) for much help in the field and for their skillful preparation. C. Wimmer-Pfeil (SMNS) is thanked for the production of thin sections. We further thank E.-M. Griebeler (University of Mainz, Germany) and D. Seegis (SMNS) for discussion and H. Woodward, J. Cubo, one anonymous reviewer, as well as the editor J. Botha-Brink for helpful comments on previous versions of the manuscript.

\section{LITERATURE CITED}

Amprino, R. 1947. La structure du tissu osseux envisagée comme expression de différences dans la vitesse de l'accroisement. Archives de Biologie 58:315-330.

Benton, M. J. 1984. Rauisuchians and the success of dinosaurs. Nature 310:101.

Botha-Brink, J., and R. M. H. Smith. 2011. Osteohistology of the Triassic archosauromorphs Prolacerta, Proterosuchus, Euparkeria, and Erythrosuchus from the Karoo Basin of South Africa. Journal of Vertebrate Paleontology 31:1238-1254.

Botha-Brink, J., D. Codron, A. K. Huttenlocker, K. D. Angielczyk, and M. Ruta. 2016. Breeding young as a survival strategy during Earth's greatest mass extinction. Scientific Reports 6:24053. doi: 10.1038/ srep24053.

Brusatte, S. L, M. J. Benton, J. B. Desojo, and M. C. Langer. 2010. The higher-level phylogeny of Archosauria (Tetrapoda: Diapsida). Journal of Systematic Palaeontology 8:3-47.

Brusatte, S. L., M. J. Benton, M. Ruta, and G. T. Lloyd. 2008. Superiority, competition, and opportunism in the evolutionary radiation of dinosaurs. Science 321:1485-1488.

Buffrénil, V. de, and J. M. Mazin. 1990. Bone histology of the ichthyosaurs: comparative data and functional interpretation. Paleobiology 16:435-447.

Buffrénil, V. de, and J. M. Mazin. 1992. Contribution de l'histologie osseuse a l'interpretation paléobiologique du genre Placodus Agassiz, 1833 (Reptilia, Placodontia). Révue de Paléobiologie 11:397407.

Canoville, A, V. de Buffrénil, and M. Laurin. 2016. Microanatomical diversity of amniote ribs: an exploratory quantitative study. Biological Journal of the Linnean Society. doi: 10.1111/bij.12779.

Carrier, D. R., and C. G. Farmer. 2000. The evolution of pelvic aspiration in archosaurs. Paleobiology 26:271-293.

Castanet, J., K. Curry-Rogers, J. Cubo, and J. J. Boisard. 2000. Periosteal bone growth rates in extant ratites (ostriche and emu). Implications for assessing growth in dinosaurs. Comptes Rendus de l'Académie des Sciences, Series III, Sciences de la Vie 323:543-550.

Castanet, J., H. Francillon-Vieillot, F. J. Meunier, and A. de Ricqlès. 1993. Bone and individual aging; pp. 245-283 in B. K. Hall (ed.) Bone Volume 7: Bone Growth. CRC Press, Boca Raton, Florida.

Cerda, I. A. 2009. Consideraciones sobre la histogénesis de las costillas cervicales en los dinosaurios saurópodos. Ameghiniana 46:193-198.

Cerda, I. A., J. B. Desojo, T. M. Scheyer, and C. L. Schultz. 2013. Osteoderm microstructure of "rauisuchian" archosaurs from South America. Geobios 46:273-283.

Chinsamy, A., and A. Elzanowski. 2001. Bone histology. Evolution of growth pattern in birds. Nature 412:402-403.

Chinsamy-Turan, A. 2005. The Microstructure of Dinosaur Bone. The Johns Hopkins University Press, Baltimore, Maryland, $195 \mathrm{pp}$.

Cubo, J., N. Le Roy, C. Martinez-Maza, and L. Montes. 2012. Paleohistological estimation of bone growth rate in extinct archosaurs. Paleobiology 38:335-349.

Cubo, J., F. Ponton, M. Laurin, E. de Margerie, and J. Castanet. 2005. Phylogenetic signal in bone microstructure of sauropsids. Systematic Biology 54:562-574.

Curry, K. A. 1999. Ontogenetic histology of Apatosaurus (Dinosauria: Sauropoda): new insights on growth rates and longevity. Journal of Vertebrate Paleontology 19:654-665.

Currey, J. D. 2002. Bones: Structure and Mechanics. Princeton University Press, Princeton, New Jersey, 456 pp.

Desojo, J. B., and S. F. Vizcaíno. 2009. Jaw biomechanics in the South American aetosaur Neoaetosauroides engaeus. Paläontolologische Zeitschrift 83:499-510. de Margerie, E., J. Cubo, and J. Castanet. 2002. Bone typology and growth rate: testing and quantifying "Amprino's rule" in the mallard (Anas platyrhynchos). Comptes Rendus de l'Académie des Sciences de Paris: Biologies 325:221-230.

Ezcurra, M. D. 2016. The phylogenetic relationships of basal archosauromorphs, with an emphasis on the systematics of proterosuchian archosauriforms. PeerJ 4:e1778. doi: 10.7717/peerj.1778

Ezcurra, M. D., T. M. Scheyer, and R. J. Butler. 2014. The origin and early evolution of Sauria: reassessing the Permian saurian fossil record and the timing of the crocodile-lizard divergence. PLoS ONE 9:e89165.

Erickson, G. M. 2005. Assessing dinosaur growth patterns: a microscopic revolution. Trends in Ecology and Evolution 20:677-684.

Erickson, G. M. 2014. On dinosaur growth. Annual Review of Earth and Planetary Sciences. 42:675-97.

Foth, C., M. D. Ezcurra, R. B. Sookias, S. L. Brusatte, and R. J. Butler. 2016. Unappreciated diversification of stem archosaurs during the Middle Triassic predated the dominance of dinosaurs. BMC Evolutionary Biology 16:188. doi: 10.1186/s12862-016-0761-6.

Francillon-Vieillot, H., J. Castanet, J. Géraudie, F. J. Meunier, J. Y. Sire, L. Zylberberg, and A. de Ricqlès. 1990. Microstructure and mineralization of vertebrate skeletal tissues; pp. 471-530 in J. Carter (ed.), Skeletal Biomineralization: Patterns, Processes and Evolutionary Trends. Van Nostrand Reinhold, New York.

Gauthier, J. A., S. J. Nesbitt, E. R. Schachner, G. S. Bever, and W. G. Joyce. 2011. The bipedal stem crocodilian Poposaurus gracilis: inferring function in fossils and innovation in archosaur locomotion. Bulletin of the Peabody Museum of Natural History 52:107-126.

Gower, D. J. 1999. Cranial osteology of a new rauisuchian archosaur from the Middle Triassic of southern Germany. Stuttgarter Beiträge zur Naturkunde B 280:1-49.

Gower, D. J. 2002. Braincase evolution in suchian archosaurs (Reptilia: Diapsida): evidence from the rauisuchian Batrachotomus kupferzellensis. Zoological Journal of the Linnean Society 136:49-76.

Gower, D. J., and R. R. Schoch. 2009. Postcranial anatomy of the rauisuchian archosaur Batrachotomus kupferzellensis. Journal of Vertebrate Paleontology 29:103-122.

Hua, S., and V. de Buffrénil. 1996. Bone histology as a clue in the interpretation of functional adapatations in the Thalattosuchia (Reptilia: Crocodylia). Journal of Vertebrate Paleontology 16:703-717.

Horner, J. R., and K. Padian. 2004. Age and growth dynamics of Tyrannosaurus rex. Proceedings of the Royal Society, London B Biological Sciences 271:1875-1880.

Horner, J. R., K. Padian, and A. de Ricqlès. 2000. Long bone histology of the hadrosaurid dinosaur Maiasaura peeblesorum: growth dynamics and physiology based on an ontogenetic series of skeletal elements. Journal of Vertebrate Paleontology 20:115-129.

Houssaye, A. 2013. Bone histology of aquatic reptiles: what does it tell us about secondary adaptation to an aquatic life? Biological Journal of the Linnean Society 108:3-21.

Houssaye, A., T. M. Scheyer, C. Kolb, V. Fischer, and P. M. Sander. 2014. A new look at ichthyosaur long bone microanatomy and histology: implications for their adaptation to an aquatic life. PLoS ONE 9:e95637.

Karkach, A. S. 2006. Trajectories and models of individual growth. Demographic Research 15:347-400.

Klein, N., and P. M. Sander. 2007. Bone histology and growth of the prosauropod dinosaur Plateosaurus from the Norian bonebeds of Trossingen (Germany) and Frick (Switzerland). Special Papers in Paleontology 77:169-206.

Klein, N., and T. M. Scheyer. 2017. Microanatomy and life history in Palaeopleurosaurus (Rhynchocephalia: Pleurosauridae) from the Early Jurassic of Germany. The Science of Nature 104:4. doi: 10.1007/s00114-016-1427-3.

Klein, N., A. Christian, and M. P. Sander. 2012a. Histology shows that elongated neck ribs in sauropod dinosaurs are ossified tendons. Biology Letters 8:1032-1035.

Klein, N., A. Houssaye, J. M. Neenan, and T. M. Scheyer. 2015a. Long bone histology and microanatomy of Placodontia (Diapsida: Sauropterygia). Contributions to Zoology 84:59-84.

Klein, N., J. Neenan, T. M. Scheyer, and E. M. Griebeler. 2015b. Growth patterns and life history strategies in Placodontia (Diapsida: Sauroptertygia). Royal Society Open Science 2:140440.

Klein, N., P. M. Sander, K. Stein, J. Le Loeuff, J. Carballido, and E. Buffetaut. 2012b. Modified laminar bone in Ampelosaurus atacis 
and other titanosaurs (Sauropoda): implications for life history and physiology. PLoS ONE 7:e36907.

Köhler, M., N. Marin Moratalla, X. Jordana, and R. Aanes. 2012. Seasonal bone growth and physiology in endotherms shed light on dinosaur physiology. Nature 487:358-361.

Konietzko-Meier, D., and A. Schmitt 2013. A histological study of a femur of Plagiosuchus, a Middle Triassic temnospondyl amphibian from southern Germany, using thin sections and micro-CT scanning; in E. W. A. Mulder, J. W. M. Jagt, and A. S. Schulp (eds.), The Sunday's Child of Dutch Earth Sciences-A Tribute To Bert Boekschoten on the Occasion of His 80th Birthday. Geoscience Journal 92(2-3):97-108.

Legendre, L. J., L. Segalen, and J. Cubo. 2013. Evidence for high growth rate in Euparkeria obtained using a new paleohistological inference model for the humerus. Journal of Vetrebrate Paleontology 33:1343-1350.

Legendre, L. J., G. Guénard, J. Botha-Brink, and J. Cubo. 2016. Palaeohistological evidence for ancestral high metabolic rate in archosaurs. Systematic Biology. doi: 10.1093/sysbio/syw033.

Li, C., Wu, X. C., Zhao, L. J., Sato, T., and L. T. Wang. 2012. A new archosaur (Diapsida, Archosauriformes) from the marine Triassic of China. Journal of Vertebrate Paleontology 32:1064-1081.

Maddison, W. P., and D. R. Maddison. 2017. Mesquite: a modular system for evolutionary analysis. Version 3.2. Available at http://mesquite project.org.

Montes, L., J. Castanet, and J. Cubo. 2010. Relationship between bone growth rate and bone tissue organization in amniotes: first test of Amprino's rule in a phylogenetic context. Animal Biology 60:25-41.

Montes, L., N. Le Roy, M. Perret, V. de Buffrénil, J. Castanet, and J. Cubo. 2007. Relationships between bone growth rate, body mass and resting metabolic rate in growing amniotes: a phylogenetic approach. Biological Journal of the Linnean Society 92:63-76.

Mukherjee, D. 2015. New insights from bone microanatomy of the Late Triassic Hyperodapedon (Archosauromorpha, Rhynchosauria): implications for archosauromorph growth strategy. Palaeontology 58:313-339.

Nesbitt, S. J. 2006. The anatomy of Effigia okeeffeae (Archosauria, Suchia), theropod-like convergence, and the distribution of related taxa. Bulletin of the American Museum of Natural History 302:1-84.

Nesbitt, S. J. 2011. The early evolution of archosaurs. Relationships and the origin of major clades. Bulletin of the American Museum of Natural History 352:1-292.

Nesbitt, S. J., J. B. Desojo, and R. B. Irmis. 2013. Anatomy, phylogeny and palaeobiology of early archosaurs and their kin. Geological Society, London, Special Publications 379:1-608.

Padian, K., and J. R. Horner. 2004. Physiology; pp. 660-671 in D. Weishampel, P. Dodson, and H. Osmólska (eds.), The Dinosauria, second edition. University of California Press, Berkeley, California.

Padian, K., J. R. Horner, and A. de Ricqlès. 2004. Growth in small dinosaurs and pterosaurs: the evolution of archosaurian growth strategies. Journal of Vertebrate Paleontology 24:555-571.

Perry, S. F., and P. M. Sander. 2004. Reconstructing the evolution of the respiratory apparatus in tetrapods. Respiratory Physiology \& Neurobiology 144:125-139.

Ricqlès, A. de. 1968. Recherches paléohistologiques sur les os longs des tétrapodes; I-origine du tissu osseux plexiforme des dinosauriens sauropodes. Annales de Paléontologie 54:133-146.

Ricqlès, A. de, K. Padian, and J. A. Horner. 2003. On the bone histology of some Triassic pseudosuchian archosaurs and related taxa. Annales de Paléontologie 89:67-101.

Ricqlès, A. de, K. Padian, F. Knoll, and J. A. Horner. 2008. On the origin of high growth rates in archosaurs and their ancient relatives: complementary histological studies on Triassic archosauriforms and the problem of a "phylogenetic signal" in bone histology. Annales de Paléontologie 94:57-76.

Sander, P. M., and P. Andrássy. 2006. Lines of arrested growth and long bone histology in Pleistocene large mammals from Germany: what do they tell us about dinosaur physiology? Palaeontographica Abteilung A 227:143-159.
Sander, P. M., and C. Tückmantel. 2003. Bone lamina thickness, bone apposition rates, and age estimates in sauropod humeri and femora. Paläontologische Zeitschrift 76:161-172.

Sander, P. M., N. Klein, E. Buffetaut, G. Cuny, V. Suteethorn, and J. Le Loeuff. 2004. Adaptive radiation in sauropod dinosaurs: bone histology indicates rapid evolution of giant body size through acceleration. Organisms, Diversity \& Evolution 4:165173

Sander, P. M., N. Klein, K. Stein, and O. Wings. 2011. Sauropod bone histology and its implications for sauropod biology; pp. 276-302 in N. Klein, K. Remes, C. T. Gee, and P. M. Sander (eds.), Biology of the Sauropod Dinosaurs: Understanding the Life of Giants. Indiana University Press, Bloomington, Indiana.

Scheyer, T. M., and J. B. Desojo. 2011. Palaeohistology and external microanatomy of rauisuchian osteoderms (Archosauria: Pseudosuchia). Palaeontology 54:1289-1302.

Scheyer, T. M., J. B. Desojo, and I. A. Cerda. 2014. Bone histology of phytosaur, aetosaur, and other archosauriform osteoderms (Eureptilia, Archosauromorpha). The Anatomical Record 297:240-260.

Schoch, R. R., and D. Seegis. 2016. A Middle Triassic palaeontological gold mine: the vertebrate deposits of Vellberg (Germany). Palaeogeography, Palaeoclimatology, Palaeoecology 459:249-267.

Seymour, R. S., C. L. Bennett-Stamper, S. D. Johnston, D. R. Carrier, and G. C. Grigg. 2004. Evidence for endothermic ancestors of crocodiles at the stem of archosaur evolution. Physiological and Biochemical Zoology 77:1051-1067.

Starck, J. M., and A. Chinsamy. 2002. Bone microstructure and developmental plasticity in birds and other dinosaurs. Journal of Morphology 254:232-246.

Sues, H. D., and R. R. Schoch. 2013. Reassessment of cf. Halticosaurus orbitoangulatus from the Upper Triassic (Norian) of Germany-a pseudosuchian, not a dinosaur. Zoological Journal of the Linnean Society 168:859-872.

Toljagic, O., and R. J. Butler. 2013. Triassic/Jurassic mass extinction as trigger for the Mesozoic radiation of crocodylomorphs. Biology Letters 9:20130095.

Veiga, F. H., M. B. Soares, and J. M. Sayão. 2015. Osteohistology of hyperodapedontine rhynchosaurs from the Upper Triassic of Southern Brazil. Acta Palaeontologica Polonica 60:829-836.

Waskow, K., and P. M. Sander. 2014. Growth record and histological variation in the dorsal ribs of Camarasaurus sp. (Sauropoda). Journal of Vertebrate Paleontology 34:852-869.

Werning, S., and R. B. Irmis. 2011. Reconstructing the ontogeny of the Triassic basal archosauromorph Trilophosaurus using bone histology and limbbone morphometrics. Society of Vertebrate Paleontology 31(Program and Abstracts):185A-186A.

Werning, S., and S. J. Nesbitt. 2016. Bone histology and growth in Stenaulorhynchus stockleyi (Archosauromorpha: Rhynchosauria) from the Middle Triassic of the Ruhuhu Basin of Tanzania. Comptes Rendus Palevol. doi: 10.1016/j.crpv.2015.03.004.

Wiffen, J., V. de Buffrénil, A. de Ricqlès, J.-M. Mazin. 1995. Ontogenetic evolution of bone structure in Late Cretaceous Plesiosauria from New Zealand. Geobios 28:625-640.

Witzmann, F. 2009. Comparative histology of sculptured dermal bones in basal tetrapods, and the implications for the soft tissue dermis. Palaeodiversity 2:233-270.

Witzmann, F., R. R. Schoch, A. Hilger, and N. Kardjilov. 2012. Braincase, palatoquadrate and ear region of the plagiosaurid Gerrothorax pulcherrimus from the Middle Triassic of Germany. Palaeontology 55:31-50.

Woodward, H. N., J. R. Horner, and J. O. Farlow. 2014. Quantification of intraskeletal histovariability in Alligator mississippiensis and implications for vertebrate osteohistology. PeerJ 2:e422. doi: 10.7717/ peerj. 422

Submitted June 20, 2016; revisions received February 9, 2017; accepted March 15, 2017.

Handling editor: Jennifer Botha-Brink. 